\title{
“Primitive" Discourse: Aspects of Contemporary North American Indian Representations of the Irish and of Contemporary Irish Representations of North American Indians
}

\author{
Joy Porter
}

This article contrasts a number of contemporary incidences of Irish representation of and engagement with Native Americans and their history with two Native American novels and their depictions of Ireland and the Irish, LeAnne Howe's 2001 book Shellshaker and Leslie Marmon Silko's 1999 book Gardens in the Dunes. It argues that Ireland's relationship with Native Americans and Native America's relationship with Ireland, particularly at the level of imagery and representation, is more complex than contemporary creative and critical work has tended to suggest. While the voices from Native America or Ireland that represent or refer to each other are small in number, their articulation is often powerful. Furthermore, they unlock a series of representational issues that are important to how each national entity or in the American Indian context, group of sovereign national entities, views itself within the postcolonial world. I present evidence to show that both Irish cultures and American Indian cultures have tended routinely to see each other through a cracked mirror, one reflective of colonial stereotype rather than the historical record. For interesting reasons, voices from each side have chosen to perpetuate ossified myths rather than the changing historical realities that have developed within each set of communities across time. What is needed at this juncture is for a new critical and creative relationship to be forged between Ireland and Native America, one that moves beyond stereotype and misrepresentation and instead engages the rich histories and contemporary cultures of each group of peoples. Today, as Ireland's artists and critics examine 


\section{Joy Porter}

the full texture of postcolonial Ireland and set about placing its stories in rich transnational context, it is more appropriate than ever that they begin to comprehend more fully the American Indian nations whose territory, in the realm of imagination, they continue to invade. Correspondingly, as American Indian artists and critics continue to engage with Ireland, it is important that they also move beyond reiteration of the most pervasive stereotypes about it and instead adopt a more nuanced understanding of the colonizing processes that both sets of peoples have shared. True freedom from colonial ways of thinking requires not only that we dispense with the colonizers' stereotypes about ourselves, but also that we recognize stereotypes applied to others. It is only by moving beyond the partial and telescoped version of history such stereotypes represent that dialogue can begin, a dialogue whose potential to open up new avenues of postcolonial analysis in the twenty-first century could be profound. Failure to dispense with respective stereotype and misrepresentation on either the Irish or American Indian side will hinder understanding of the shared aspects of the Irish and American Indian history of colonialism and perpetuate colonial representational ideas that have always served interests other than those of indigenous communities.

\section{Approaches to a Shared Colonial History}

No two experiences of colonialism are the same, but the links between Irish and American Indian experiences of conquest are nonetheless slowly being unearthed. We have known since 1945 from D.B. Quinn for example, that English colonists in Ireland gleaned ideas about plantations and subjugation from the Spanish empire's successes in the Americas. Early figures such as Walter Ralegh, Francis Drake, Humphrey Gilbert and Sir Richard Grenville all benefited from their experience colonizing both the Americas and Ireland. Similarly, Cromwell's approach to Irish subjugation had clear links with Spanish practices and he sold many Irish people into West Indian slavery. Indeed, Ireland can, as Nicholas Canny argues, be seen as a sort of laboratory experiment for the colonizing of North America and as his work with Anthony Pagden reveals, settler communities across time have tended to share a common set of characteristics and to have faced common problems.

Certainly, the Irish and American Indians have shared mythologized identities generated by those who sought to culturally dominate them. Both were characterized as practicing cannibalism, bestiality, sexual excess, godlessness, and immorality, and as having common approaches to war, dress, and habitation. A shared American Indian/Irish heritage in this regard can be traced back to the Greek geographer Strabo. There are also reports of the Irish being descended from the cannibal Scythians as early as Herodotus and the same descent was reckoned for American Indians (Rawson 345). In sum, American Indians and the Irish have occupied the same "wild" space in the Western imagination. Once eroticized as the outer limit of the known world, with discovery of a new limit in the "New World," Ireland's mythologized identity shifted onto "American 
Indians." Indeed, in the seventeenth century, as Peter Mason has pointed out, American Indians were rated slightly more highly than the Irish on the scale of European civilization. By the eighteenth century, "American Indians" was a term used for a number of groups who deviated from orthodoxy (Mason 61, 63) and by 1869 Trinity professor John Pentland Mahaffy confidently linked Celts, American Indians and a whole panoply of subaltern groups in his supremely racist and triumphalist Twelve Lectures on Primitive Civilizations and Their Physical Conditions.

Such thinking created one particularly ugly and deeply resonant connection between American Indian and Irish experiences of colonization across time as Katie Kane has explored. Writers described the massacres at Drogheda in 1649 and Sand Creek in 1864 as the necessary extermination of a parasitic indigenous population. An English poet wrote of how Sir Charles Coote at Drogheda "[d]id kill the Nitts, that they might not growe Lice." John Chivington, the man in charge of the Third Cavalry Regiment of Colorado Territory that murdered and mutilated the Cheyenne and Arapaho men, women, and children who surrendered at Sand Creek also publicly explained his American Indian policy as being to "kill and scalp all, little and big; that nits made lice."

This is not to suggest that the experience of colonialism of the Irish can simply or easily be transposed onto Native Americans. As Fintan O'Toole puts it in his study of a powerful Irish figure who went on to dominate within American Indian culture White Savage: William Johnson and the Invention of America, "One thing leads to another" (1), that is, the conquest of one set of peoples interconnects with the eventual conquest of another. O'Toole's subject converts from Roman Catholicism to serve his British colonial overlords but once in the New World, uses his Irish heritage to gain a supreme position within Iroquois American Indian society. While O'Toole at no point shies away from the awkward truth that "the wounded pride of the Irish dispossessed often found a salve in the joy of dominating others," he makes sure his readers also recognize the empathy and cultural reciprocity that Johnson shared with his American Indian wife, comrades, and political allies (294). Perhaps it will ultimately be through examination of men like Johnson and significant American Indian acculturative leaders such as the Scottish-Creek-French Alexander McGillivray (c1759-1793) and the Scottish-Cherokee John Ross (1790-1866) that the complex history of successive waves of conquest will be best understood. One further point of complexity is also worth noting. In the discussion that follows, the examples provided concerning Ireland are broad-based and cross-temporal. They cannot be held to stand metonymically for "Ireland" in all its diversity across time. Similarly, the two American Indian novels discussed are no more than two primary cultural examples to date of American Indian artistic use of Irish themes. They too cannot be held to encapsulate fully the variety of opinion held over time by highly diverse indigenous North American peoples about Ireland and its peoples. With this in mind however, it may still be possible to discern something useful and 


\section{Joy Porter}

revealing about Irish and American Indian representations of each other and to shed fresh light on the critical response to this relationship to date.

\section{Irish Representations of North American American Indians}

To date, when critics have been confronted by stereotypes about American Indians put forward by Irish writers and artists, the tendency has been, as in Elizabeth Butler Cullingford's case in Ireland's Others discussed below, to suggest that such stereotyping is actually some form of deft cultural border crossing or liminality that transcends discursive evaluation. Perhaps a better way to view the phenomenon would be to interrogate it critically as a form of strategic essentialism in the sense Gayatri Spivak has used the term, that is, to subject it to the same sustained analysis that Joseph Lennon has applied to Irish Orientalism in his magisterial text Irish Orientalism: A Literary and Intellectual History. Lennon found the discourse of Irish Orientalism (meaning the discourse about Asian, West Asian, and North African cultures when collectively seen by Europeans), to be "strategic in its deployment, if often complicit with the overall discourse of imperialism" (xxviii). The same conclusion may await an analogous extensive study of the semiotic history of Irish representations of North American Indians, but in the meantime, it is useful here to at least present a counterargument to the reading put forward by Cullingford.

Cullingford sees the fascination of Irish artists with the image of the American Indian, as yet another instance of "neglect of the proximate in favor of the exotic," that is, neglect by Ireland of the larger, closer, colonizing island, in favor of more mysterious lands beyond. She suggests it is analogous to what James Joyce did in his 1907 Trieste lecture entitled, "Ireland, Island of Saints and Sages." Here he claimed that the Irish language was "oriental in origin, and has been identified by many philologists with the ancient language of the Phoenicians." Cullingford argues that this sort of reaching out exemplifies, in Luke Gibbons' phrase, "lateral journeys along the margins which short-circuit the colonial divide" (qtd. in Cullingford 160, 80). ${ }^{1}$ This idea may initially seem attractive, especially to an Irish readership, since short-circuiting colonial divides sounds like a radical and positive thing to do. Unfortunately, in great part nothing like this has occurred when Irish culture has reached out towards American Indian culture. Instead, if anything, Irish artistic relationships to American Indians have tended to reinscribed stereotypes and to reinforced colonial divisions. Why? Because it has not been actual American Indian cultures that Irish art has sought connection with at all, but instead, invented colonial caricatures of American Indianness that have served, and continue predominantly to serve, the varied interests of the non-native world.

Far from skirting colonial divisions, most Irish representation of and identification with American Indians has been firmly embedded within them. What Cullingford describes in her chapter "John Wayne Fan or Dances With Wolves Revisionist?: Analogy and Ambiguity in the Irish Western" should be seen in the 
context of a long history of American Indians and non-American Indians "playing" Indian within the limitations of these firmly entrenched representational boundaries. This is because American Indian identity in the Irish Western, and in most non-American Indian representation of American Indians, is invented. American Indians have been forced to "play Indian" since contact because of a resilient determination within the non-Indian world, including Ireland, to imagine Native America in relationship to its own concerns rather than to engage with the actuality of American Indian peoples' presence and their inherent diversity. There is little evidence, however attractive the idea might seem, to support the notion that Irish artists have somehow transcended this powerful and corrosive representational dynamic. Instead, Irish artists have reiterated colonial misrepresentations and/or variously and strategically "played Indian," that is, acted out or juxtaposed Irish concerns alongside stereotypical notions of "Indianness" over time. $^{2}$

Using monetary metaphors, Cullingford lists points of correspondence between Irish writing and filmmaking and the Western. She describes the American West as "an image bank for contemporary Irish film, poetry and literature" while recognizing that the currency in this bank is highly politically ambiguous, because "an Irishman's release from colonial constraint may entail the expropriation of a Native American" (160). But in truth there is little ambiguity at play in most Irish filmmaking and writing linked to the Western. Instead, the artistic examples Cullingford cites unambiguously expropriate American Indian culture, offensively cartoon American Indian identity or feed directly into narratives that dangerously misrepresent American Indian history. An example is the cinematic identification of Irish children with American Indians, a phenomenon that offensively taps into a centuries-old imperial stereotype of American Indians as helpless children. ${ }^{3}$ Others include the fascination with Sitting Bull in works such as Jennifer Johnston's dramatic monologue Mustn't Forget High Noon (1989), the satire of Northern Catholic identification with Native America in Carthaginians by Frank McGuinness and the preference of Paddy's son in Roddy Doyle's Paddy Clarke $\mathrm{Ha} \mathrm{Ha} \mathrm{Ha}$ for Geronimo as opposed to Daniel Boone. Arguably these writers are aware of American Indian stereotypes and are intent upon ridiculing them through their characters and each engages the reader ironically. They also have in common that they treat only the imagery of the Native American past; they deal only with non-American Indian perspectives concerning American Indian tragedy and defeat that stem either from the era of Manifest Destiny or from the stereotypes prevalent in the 1960s and then relate them to Irish concerns. The American Indian, in Irish artistic treatment, and in the "bank" of American Western imagery Irish artistic treatment draws upon, is never coeval with nonAmerican Indians. He (and it invariably is a he) is a static figure of yesteryear that exists almost exclusively to reflect values currently deemed valuable or lost within Irish culture. ${ }^{4}$

The Irish artistic emphasis upon Sitting Bull (Hunkpapa Lakota, c1831-1890) and Geronimo (Bedonkohe Apache, 1829-1909) needs to be seen for what it is. 
In essence it is yet another attempt to ossify American Indian culture in the time period conjured by the Western sometime between 1825 and the close of the frontier in 1890, a period after which America decided that the American Indian had been defeated and would therefore "vanish." "Tragic" figures like Sitting Bull and Geronimo have therefore been presented by non-American Indian culture as "the last of their kind." This is a comfortable variety of American fiction that belies that the American Indian struggle for sovereignty and self-determination is ongoing and still fought sometimes physically, on many fronts. In fact, Sitting Bull's peoples and the rest of the Oceti Shakowan, the Great Sioux Nation (made up of Santees, Oglalas, Sicangus, Minneconjous, Yanktons, Sihasapas and Hunkpapas) today occupy hundreds of thousands of acres in the Northern Plains and their spokespeople remain among the strongest voices in American Indian intellectual and cultural life. Sitting Bull and Geronimo, it should be remembered, fought just one stage in a long and current battle to save American Indian lives and to retain American Indian land and cultural autonomy. ${ }^{5}$ It was and remains a struggle fought first and foremost at community level despite the non-Indian fascination with the eloquence and resistance of specific Indian individuals.

Cullingford does acknowledge in her study that Seamus Heaney's elegizing of Sitting Bull as a symbol of "loss and origins," "cannot be too seamlessly aligned with the victimization and resistance of the Irish." This is certainly true, since Tatanka-Iyotanka, Sitting Bull, was a complex and deeply spiritual leader who is much more than a symbol of loss and origins. In any case, perhaps the main reason the Hunkpapa Lakota Sitting Bull and the Lakotas in general are so well known within popular culture is precisely because in one great battle they did not lose. They won, famously, at Little Big Horn in 1876 when American Indians slaughtered panicked American soldiers as if they were herds of buffalo. ${ }^{6}$ Something else that makes alignment with Irish "victimhood" awkward is that the Sioux, like the Zulu, aggressively engaged in their own "subimperialisms" during the first half of the nineteenth century, subjugating the Crow and, in total contradiction of the gloss given in Dances With Wolves, the Pawnee. ${ }^{7}$ Furthermore, Sitting Bull's bands took refuge from the ferocious American aggression that ensued after Little Big Horn by fleeing to Canada and the jurisdiction of the woman Sitting Bull referred to as "the Great White Grandmother, the Queen." This flight to Canada ultimately proved futile and his own people killed Sitting Bull on 16 December 1890. Sitting Bull may or may not be symbolic of "origins," but he certainly cannot be seen as universally representative of the response to colonialism of by all American Indian peoples, or for that matter, even of the Sioux Nation. Sitting Bull and Goyathlay (Geronimo) simply exemplify the forms of American Indian leadership that have proved most amenable to a nonAmerican Indian representational imperative at the expense of other leaders of the period, like Victorio, Mangus Colorado, Cochise, and all the Sioux leaders who chose not to follow Sitting Bull, including the perhaps justifiably maligned John Grass. ${ }^{8}$ In sum, as Vine Deloria, Jr. once pointed out, a scowling Sitting Bull and a sullen Geronimo symbolize a convenient American narrative and they appear 
only to personalize the supposed fortunes of all their kind: they "symbolize not living people but the historic fate of a nation overwhelmed by the inevitability of history" (27). Their image in the Irish artistic context maps primarily onto non-American Indian needs and stems from a non-American Indian desire to perceive American Indian peoples in terms of a dubious notion of quintessential authenticity.

Cullingford tells her readers that "Northern Catholics frequently identify with the Native American underdogs" (183). As evidence she explains that Bobby Sands used to sign himself "Geronimo," that there was a Geronimo mural inside Long Kesh prison, and that Paul Muldoon makes an analogy between an Oglala Sioux trickster and an I.R.A. man in his poem "The More a Man Has." Leaving Cullingford's easy conflation of Northern Catholics with the I.R.A. to one side, were there an I.R.A. identification with Native America, it would be with the invented American Indian imagery of the kind broadcast on television in Rathcoole when Bobby Sands grew up rather than with contemporary Indian peoples. In one sense, this identification with Indians of the past is odd, in that the Black American civil rights impetus that inspired Catholic civil rights in the North of Ireland in 1967-68 also inspired Red Power and the American Indian Movement of the late 1960s and 1970s. American Indians in the United States were actually difficult to ignore militarily and culturally and in terms of civil rights during the late 1960s and 1970s. Disproportionate numbers of American Indians fought in Vietnam; Kiowa author N. Scott Momaday won the Pulitzer Prize for fiction in 1969; and American Indian peoples were consistently inventive and persistent in their work as activists, occupying Alcatraz in 1969 and Wounded Knee in 1973. Bobby Sands had living American Indians also engaged in civil rights struggle with whom he could have chosen to identify, instead of with the Chiricahua Apache Goyathlay (Geronimo) whose better-known name was a gift from the Mexicans he so despised and who died in 1909. This is not to deny that Geronimo and Bobby Sands have something in common. Like many individual American Indians, Geronimo was effectively a long-term prisoner of war, spending decades in forced exile far from his homelands. ${ }^{9}$ And of course, Bobby Sands and those who surrounded him were not alone in finding strength in Geronimo's image. As one historian has remarked, the mixture of hype, lies, and truth that has surrounded Geronimo over time has repeatedly proved "almost irresistible to non-American Indians under peril or stress" (Sonnichsen, 5). The Paris underworld invented its own counter-cultural apaches at the beginning of the twentieth century and of course, during World War II, paratroopers hurled themselves into space shouting "GERONIMO!"

Whilst Irish Republicans have primarily reached out to Indians of the past, there have been instances when the agendas of coeval American groups and those of certain Irish Republican groups have coalesced. For example, in 1995 when American Indian Movement spokesman Vernon Bellecourt attended Sinn Fein's Ard Fheis and was interviewed in An Phoblacht/Republican News; in 1997 when another celebrity AIM figure, Dennis Banks, brought his "Sacred Run" 
to Ireland; and in 2000, when the Star Neighbourhood Centre commissioned a mural at Hillman Street, North Belfast depicting Leonard Peltier, as a "Native American U.S. Political Prisoner."10 Overall, the Irish republican connection with Native Americans, at least in the current era, has been primarily with AIM, one of many foreign groups, including E.T.A. (Euskadi TaAskatasuma/Basque Homeland \& Freedom) and the P.L.O. (Palestine Liberation Organization) with whom republicans have claimed ideological affinity. It should also be recognised that so much of Paul Muldoon's muddy writings have as a primary strength an engagement with the specifics of American Indian history and a resonant awareness of important American Indian names of the past. It may not be the case that Muldoon's American Indians are, as Jacqueline McCurry posits, "Ulster Catholics in disguise," but that might be part of what they are nonetheless (46).

Even so, it remains the case that the emphasis upon the icon of the "traditional American Indian chief" - who is wise, stoic, commendably militarist, and an authoritarian leader - is just as fake a representation of American Indian culture as is the Dances With Wolves idealized view of American Indian society as egalitarian, feminist, and committed to peace, spirituality, and unity with nature. Furthermore, Sitting Bull and Geronimo were probably respected most by their communities as figures of spiritual rather than military power and both denied that they were "chiefs," a term not used by Indians. Both Irish and American discourse tends to ignore aspects of each figure that undermine their currency as "authentic" American Indians opposed to all aspects of modernity and civilization. In fact, having been forced to give up their way of life, each leader excelled as a homesteader; Geronimo raising watermelons and vegetables at Fort Sill, Oklahoma and Sitting Bull tending his farm on Grand River, in present-day South Dakota. Both men also commercially exploited their images. Sitting Bull toured with Buffalo Bill. Geronimo made money at fairs and spectacles, selling his shirt buttons to the people who flocked to see him. He even dictated his memoirs. In sum, Sitting Bull and Geronimo are two leaders reviled by non-Indians prior to their incarceration and revered thereafter as emblematic, even superhuman, symbols of their people; peoples who by implication are deemed to have disappeared at the same time as their most famous "hostile" leaders.

That Irish artists can find an American Indian image that serves their needs, and link it variously to specific figures or to groups like the Sioux, Apache, or the Hopi (Wolves), does not make their engagement with American Indian culture any less problematic. Irish artists are not operating within an ambiguous discursive space that transcends or short-circuits colonial divides. Rather, they are perpetuating a highly politicized representational stance that demands critical interrogation.

Unlike Joyce's ancient Phoenicians, American Indian peoples have been and remain contemporary with their misrepresentation by Irish artists and filmmakers. Real people and real communities are affected by the stereotype Irish artists have perpetuated and engaged with. Consider, as an example, the Pine Ridge 
Reservation, Shannon County, South Dakota where Dances With Wolves was shot and where living conditions are an outrage. American Indians on the Pine Ridge Reservation and off-reservation trust land in 1989 experienced a poverty rate of 67 percent; the sort of poverty has been the case there for at least fifty years. ${ }^{11}$ Desperate conditions at Pine Ridge are symptomatic of chronic conditions generally for American Indians living within the United States. According to 1992 data:

American Indians experience twelve times the U.S. national rate ... of malnutrition, nine times the rate of alcoholism, seven times the rate of infant mortality, five times the rate of death by exposure, [with the] present life-expectancy of a reservationbased male [amounting to] 44.6 years; reservation-based women can expect to live less than three years longer. ${ }^{12}$

American Indians are amongst the poorest of the American poor. In 1989, the income gap between American Indians and "white" Americans stood at 54 percent and it has risen since with single-parent American Indian women most acutely affected by the so-called "feminization" of American poverty since the 1970s (Davis, 175-179). An October 2002 U.S. Census Bureau report noted that the lowest median household income in the United States was Buffalo County, South Dakota, home to the Crow Creek American Indian Reservation. ${ }^{13}$

It is these real, rather than imaginary, American Indians who are affected by stereotypical portrayal. Few people have put the issue better than American Indian spokeswoman Suzan Harjo when testifying in 1988 before the U.S. Civil Rights Commission. She said:

Everyone has that same old movie running through their heads, and American Indians are identified as an era, not as a people. ... We have a richness of cultural underpinnings without which we would not be able to survive today's conditions of outrageously high unemployment, staggering alcoholism, the highest rate of teenage suicide of any population in this country, which comes from low self-esteem, which comes from having those kids elders . . . mocked, dehumanized, cartooned, stereotyped. This is what is causing the deaths of many of our children. (qtd. in Hurtado 543)

Clinicians Eduardo and Bonnie Duran support Harjo's linkage of misrepresentation with enormously high rates of American Indian alcoholism and suicide. They connect high rates of anxiety, depression, and psychological dysfunction in American Indian communities and individuals with what they call "soul wound" experienced as a result of colonialism and its attendant injustices including persistent stereotyping (Duran 1990; Duran and Duran 1995). 
My point here is that Irish misrepresentation of the diversity and historical dynamism of American Indian cultures does not operate within a vacuum. It feeds into a larger historical discourse with current and quantifiable social implications. In sum, the alignment of Irish colonial victimhood with a stereotype of American Indian victimhood does not legitimate Irish misrepresentation of American Indian culture. Rather, misrepresentation is just that, misrepresentation. Scholarship on Ireland must consider seriously the historical and representational issues at play whenever anti-American Indian stereotypes are re-iterated, rather than attempting to create some blameless space on "the margins" of colonial discourse.

In Ireland's Others Cullingford argues, "Most Northern Catholics, even if they begin as John Wayne fans, end up as Dances With Wolves revisionists" (184).$^{14}$ This is probably a reductive estimation of most Northern Catholics' ability to read cinema and certainly is a reductive reading of Dances With Wolves which is not a revisionist Western at all. As the Choctaw-Cherokee-Irish writer and critic Louis Owens pointed out:

Dances With Wolves is, from beginning to end, the perfect, exquisite reenactment of the whole colonial enterprise in America, and it is the most insidious vehicle yet for this familiar message because it comes beautifully disguised as its opposite: a revisionist, politically correct western...

Costner's "love letter to the past" is precisely that: a cinematically powerful, lyrically moving, heart-string pulling love letter to an absolutely fake American past that Euro-Americans invented as a sanitized, romantic version of the ugly realities of colonization and genocide. Costner's film buys it all, repackages it, and makes more palatable the age-old clichés and unwavering metanarrative. (116)

The time has come for critics to move discussion of the Irish and the American Indians beyond the matrix of stereotype that surrounds both the Wayne and Wolves types of cinematic representation; representation that in the eyes of native and non-native commentators alike is both risible and pathetically Anglocentric.

\section{"Playing American Indian:" The Irish Fascination with the American Indian}

Given the wealth of colonial experience that links Ireland and Native America, it is perhaps surprising that when Irish culture has engaged with American Indian culture it has so often been through this prism of an imagined or invented American Indian colonial identity. The Irish have tended to engage with American Indian culture by co-opting it, or "playing Indian," that is, through bringing the metaphor of Indianness, rather than its actuality, to life. Louis Owens 
once suggested that "playing Indian" can be traced to "the colonizer's fear of what Heidegger called 'not-at-home-ness' [Unheimlichkeit], - - the inexorable deracination that comes with colonial displacement." Thus Lieutenant Dunbar (Kevin Costner in Wolves) has to "become" Indian to be at peace in his America and Huck Finn must finally light out for Indian Territory to find ease. But if this is the case, why should contemporary Irish artists feel compelled to engage in "playing Indian," a process of invention, definition, displacement, and reoccupation that Owens tells us, "acts out a strange, perverse dialectic of erotic desire and destruction"? (116-117)

Fintan O'Toole gives one answer in his 1997 book The Lie of the Land: Irish Identities. O'Toole explains that "America and Ireland represent not opposites, not a dialogue of modernity and tradition, but a continual intertwining." America's cultural sense of itself, he tells us, is partly an Irish creation and Ireland's sense of itself partly an American one $(33,45)$. This idea, that Irish and American identities are constitutive of each other, provides a partial explanation. Another, more prosaic one is that Irish artists, alongside the Irish critics whom Stephen Howe has taken to task over the issue, do not understand Ireland's heterogeneous and complex relationship to empire and are insufficiently concerned with the material and discursive bases to the comparisons they evoke.

Yet I would argue that since the phenomenon of the Irish "playing American Indian" operates at the level of the imagination, it is within that often irrational realm that the fullest explanation lies. According to Seán Farrell Moran, historians of Ireland have only in the last generation or so begun to seriously consider imagery and the realm of the imagination in Irish political and cultural life (qtd. in McBride 166-167). By comparison, for Irish literature and criticism what is imagined and how it is imagined have always been fundamental. Much has been written for example, about Joyce's recognition of the critical issue of representation for the Irish artist. Seamus Deane explains how in Ulysses Joyce dwelt on the figure of Buck Mulligan, an imitator of Oscar Wilde who embodies the servile Irish imagination. Mulligan prompts the bitter retort from Stephen that the mirror is a symbol of Irish art, "The cracked lookingglass of a servant." By comparison Joyce, Deane suggests, is the true artist presenting a truer reflection of Irish culture $(37,41)$. Following Joyce's reasoning, the propensity for Irish artists to "play Indian" is evidence of a still-servile aesthetic, evidence perhaps, of an Ireland still so unliberated that it cannot regard itself in true historical relationship to others. ${ }^{15}$

There is yet another explanation however. Matthew Arnold famously described the Irish imagination as tending to chafe against "the despotism of fact" (181). Irish artistic and critical co-optation of the American Indian across time may have at its heart this urge to cultivate transcendence of fact, an urge to constitute nationhood through imagining what may or may not actually be there. It is the same theme Joyce repeated in "Ireland, Island of Saints and Sages" when he argued "nationality ... must find its reason for being rooted in something that surpasses and transcends and informs changing things like blood and the human 
word" (165-166). A century later, the Irish nation has yet to find the transcendent reason for being that Joyce called for. Part of the problem has been that so much of what Ireland chooses to identify with never really existed in the first place. For American Indian nations, it can only be with "the despotism of fact," that positive transnational artistic and critical exchange with Ireland can begin.

That said, one can only agree with the Kiowa writer N. Scott Momaday when he states that the greatest tragedy that can befall any of us is to go unimagined (55). Irish artists are unlikely to stop imagining American Indians, but it is to be hoped that they may begin to imagine them in greater variety and to imagine them as individuals and communities within, rather than outside of, history. And if Irish artists do choose to see beyond the confines of American Indian stereotype, there will be an enormous dividend. Among many other things they will discover that contemporary American Indian and Irish artists both have a powerful sense of humor, albeit one that is sometimes based upon cartoon versions of each other. For example, in the 1989 film popular in American Indian country called Powwow Highway, Wolf Tooth and his wife Imogene decide to leave their home on the Pine Ridge Reservation because, as Imogene points out, "There's a shooting a week. It's like living in Belfast."

\section{North American Indian Representations of the Irish}

Currently there is much more written evidence of Irish imaginings of American Indians than of American Indians imagining and representing the Irish. ${ }^{17} \mathrm{On}$ the Indian side this is primarily because such work does not exist or possibly because it has not yet been unearthed, given that the long overdue recognition of the literature written in English by American Indians only began in earnest following the 1969 Pulitzer prize-winning success of N. Scott Momaday with his novel House Made of Dawn (1968). Within contemporary Native American Indian literature, one of the primary voice that has invoked the Irish is that of Leslie Marmon Silko, specifically in her book Gardens in the Dunes (1999). Here Silko uses the form of the nineteenth-century novel to present an American Indian reading of the past that transcends dominant historical narratives. The Irish, as "old Europeans," are key allies in this attack upon conventional history. "Old Europe" is a term that was introduced by Marija Gimbutas, author of The Goddesses and Gods of Old Europe: 6500-3500 B.C. in 1974 and inventor of the controversial new interdisciplinary field, archaeomythology. Gimbutas found evidence of peaceful and matrilinear pre-Indo-European "Old European" cultures that once worshipped a range of goddesses and gods and argued that the Vinca-Tordis script (excavated post 1875 in Vinča near Belgrade and elsewhere) was an Old European language. The central character in Silko's Gardens in the Dunes goes on a journey that connects "old European" and American Indian lifeways. In fact, in an ironic reversal of the ethnographies of the period, the novel exposes its readers to a spiritual ethnography conducted by its main American Indian character Indigo, who spiritually "reads" a series of gardens and their 
communities. A key moment occurs when Indigo meets another character, Aunt Bronwyn, who venerates "dancing" stones and the sacred groves that house the spirits of the dead. She has a Welsh name connoting purity and lives in a house and very cosmopolitan garden near Bath. Aunt Bronwyn struggles to protect the ancient from the modern so as to salvage an old but abiding pre-Christian spiritual understanding from loss.

It is with Aunt Bronwyn that Silko introduces some of the most radical rehistoricizing to be found within Native American literature. Bronwyn explains to Indigo how the English displacement of the Scottish was fundamentally a spiritual crime, one that caused "the fairies" to wage war against Scottish sheep. She suggests that the Irish famine of 1846 "came because the Protestants and the English knocked down the old stones." "The wars of Europe," she explains, "were the terrible consequences of centuries of crimes against the old stones and sacred groves of hazel and oak." All this, along with talk of sightings of dancers around fires on hilltops in the mist and news that "in the fog and mist; the people saw his Mother, sometimes with a child they called the Son of God," is wholly accepted by Indigo and it is the central message of the book. Ireland, and specifically Derry/Londonderry in the North of Ireland, plays a very special role in Bronwyn's version of the European past. She asks:
Did Hattie know (did anyone know) how much innocent blood spilled in Derry over the years of the occupation or how much more blood might yet spill? Ireland's suffering began with the betrayal of fairies. Those who cut down the sacred groves doomed themselves and all their descendents! (263-264) ${ }^{18}$

Clearly this kind of history is simplistic since it telescopes complex waves of conquest into one relationship, that of universalized colonizers versus stones, oak groves, fairies and presumably, the indigenous Irish, but that is not to say that the spiritual and ecological change such a history speaks to can be ignored or dismissed. ${ }^{19}$ At the very least it productively encourages us to do something unusual, that is, consider the past over very long timescales and it has interesting interrelationships with more orthodox histories. In Derry's case, it links a past most people even in Ireland may have forgotten with a present that has until recently seemed wholly irresolvable. Derry's name in Irish, "Doire," does indeed translate to "oak grove" and those oak groves were used for ships, buildings, and the plantations of English and Scottish settlers who began intensive colonization in 1585 . There is also evidence that Derry is one of the longest continuously inhabited places in Ireland, that it once had giant oak groves and that such places were used for ceremony and ritual. Derry has also been the site of recurrent destruction from 783, when the Danes burnt its abbey, to the end of the seventeenth century. Today Derry continues to suffer from the legacy of serious civil conflict and sustained terrorist activity that dates from the civil rights clashes of October 1968. Undoubtedly, as Silko's novel suggests, specific 
ecological, social, cultural and political correspondences exist between Derry's history and that of various Native American Indian communities across time. ${ }^{20}$

However, Silko's conflation of a stance that is against "the Protestants and the English" with the language of mists, fairies, and the ancient druids has a complex pedigree within Ireland (263). It connects strongly to the idealization of the primitive that accompanied all the "Celtic Revivals" in Ireland of the late eighteenth and nineteenth centuries. Ironically, in terms of Silko's pro-indigenous re-historicizing, the chief agents of such primitivism in nineteenth-century Ireland were in fact the Anglo-Irish gentry. They projected ancient Irish folkways as neutral territory on which they could connect with their Catholic compatriots. As Sinéad Garrigan Mattar has recently pointed out, by the mid-nineteenth century, their very survival as a class, "seemed to depend upon the motivating strength of romantic primitivism" (73). This was a primitivism, an idealization of an "authentic" Irish identity predating English colonial influence, that many scholars of the Irish past hold had as much to do with contemporary science and with constructions of the Orient as it did with any ancient Celtic tradition in Ireland..$^{21}$ By invoking such a romantic and primitivist version of the Irish in Gardens in the Dunes, Silko has reinscribed a set of stereotypes about the Irish that are as deeply problematic and as wedded to colonialism as those which are routinely applied to Native Americans.

Certainly Irish nationalists of the time reacted strongly against the romantic primitivism of key (Protestant) literary figures such as William Butler Yeats, Lady Gregory, and John Millington Synge, seeing it as a colonial slander against the good (Christian) name of the Irish nation. One critic said of Yeats' play The Countess Cathleen, that it depicted the old Irish as nothing more than "an impious and renegade people, crouched in degraded awe before demons, and goblins, and sprites, and sowlths, and thivishes - just like a sordid tribe of black devil-worshippers and fetish-worshippers on the Congo or the Niger" (Mattar 14). Similarly, the "Irish Ireland" movement strongly protested what it called the "Celtic sham" as patronizing, Arnoldian, and Unionist. Overall, there was deep-seated resistance from multiple Irish sources to an emphasis upon the utopian spiritual and symbolic Irish at the expense of the material and actual Irish caught up as were other Western peoples in change wrought by shifts in global capital and by industrialization (Mattar 73). As Sinéad Garrigan Mattar puts it, "The peasant whose dream Yeats emulated lived in a pre-industrial time-warp, where the circumstances of a primitive spiritual life were more real, and more desirable, than 'reality.' The peasant of the West whom he denied had fought in the Land Wars was religiously orthodox; his children were intent on leaving the fireside, discontent with the benefits of a fairy 'swoon,' to seek material comfort elsewhere" (54). In essence, the primitivism of fairies and of a posited Celtic twilight depoliticized the Irish at a time when the political power of the Irish peasant was becoming threatening (Mattar 98). It seems likely that Silko intended her novel's emphasis upon fairies, twilight, oak, spirit, and stone at least in part as a form of nationalist solidarity with another indigenous and colonized 
culture, but, as so often with things Irish, the truth in terms of the operations of history, power, representation, and stereotype, is not so simple.

Perhaps ironically, a key character in the Choctaw writer LeAnne Howe's novel Shellshaker, set in the contemporary period in and around a small town named Durant, Oklahoma, is called James Joyce. It is worth noting that the James Joyce we are more familiar with is in one sense a surprising figure for a Native American author to empathize with. He was a writer who acknowledged that British and Roman imperialism had irrevocably shattered indigenous Irish culture and who held that to try to revive it was to immerse oneself in kitsch and foolishly to attempt to navigate "by the broken lights of ancient myth" (A Portrait of the Artist as a Young Man 181). In stark contrast with Joyce's character Stephen Dedalus, who rejects the constraints of nationality, religion, and language and resolves instead upon silence, exile, and cunning, a great deal of Native American fiction, including Howe's and Silko's, has characters who find strength and succour in embeddedness, in place, sacred landscape, and in the power of the bonds of the communities therein. Be that as it may, Howe's James Joyce character in Shellshaker is extremely important to the plot. The central negative force in the novel is a flawed American Indian leader who steals many millions from his casino-rich tribe, the Choctaws, in order to give the money to James Joyce, an I.R.A. assassin whom he met in a pub in Belfast. Once in confessional mode at the novel's dénouement, Chief Redford McAlester admits: "He [James Joyce] said something like, the Choctaws and the Irish have a common enemy-the English. We both want revenge. It was a marriage made in history." McAlester then took satisfaction in watching English suffering, and reminisced, "When I'd read about a building in London exploding or an English train derailing, I'd think 'that's Choctaw revenge, too... "' (Howe 190, 191).

Howe's is a comic novel and her James Joyce is an obvious cipher. He looks exactly like the country singer Willie Nelson and speaks elliptically in incoherent sentences that are described as "stream of consciousness." The main positive character Adair, cannot understand a word he says but her partner Gore does. Joyce turns out to be disaffected with the I.R.A. because it spends too much money on bureaucracy and as a result, he helps out both Adair and the tribe so that the novel resolves happily. Gore explains with reference to Joyce: "He liked McAlester. He saw similarities between the problems of Northern Ireland and the British, and American Indians and the federal government. As a result, the I.R.A. and McAlester has history in common. Most of the money that McAlester paid them didn't go toward killing other people, but to the I.R.A. bureaucracy. That's why Joyce is angry with his own organization. That's why he turned over evidence" (Howe 208). Perhaps equally important, Joyce is also able to recognize the true worth of Adair and explain her motivations and he helps bring her together with Gore, whom she ends the novel with romantically. As Adair puts it to Gore at the novel's close, "Perfect, the only person who understood us both was an incoherent, melancholic agent for the Irish Republican Army" (Howe 218). 
Joyce is a central but not the only Irish element in this Choctaw novel. Two further talented female figures in the book have a "theme song" about an American Indian maid, "Queen of the fairies of her tribe" who marries an Irishman. It concludes:

\author{
I'll be kind and true \\ we can love and bill and coo \\ in a wigwam built of shamrocks green, \\ we'll make those red men smile \\ when you're Misses Barney-heap-much-Carney \\ from Killarney's Isle. (Howe, 153)
}

Both characters admit the song has "terrible lyrics" but sing it nonetheless amidst discussion of the money sent by their Choctaw ancestors to the starving Irish in 1847. Indeed, the book explains, it was the tribe's visit to Ireland to commemorate the "Long Walk" made during the Irish potato famine of 1847 that allowed Red McAlester to forge his links with James Joyce. One character early in the novel explains the cross-cultural reasoning and long memory for oppression that prompted Red to exact tribal revenge by proxy through the I.R.A.:

\begin{abstract}
"Remember, our tribe gave money to the Irish in 1847 for famine relief. The Irish were starving because English bureaucrats withheld food from them. Red knows. ..." She corrects herself, "Red knew history. The English, who would become the ruling class of Americans, forced American Indians to walk on the Trail of Tears, and they withheld food and supplies from them. Red appreciated historical ironies: Helping the I.R.A. get their revenge on the English was his own little joke." (Howe 94)
\end{abstract}

Red's reasoning is simplistic according to the above but elsewhere he displays a sinister callousness about both the 1847 event and about how he as an American Indian is perceived in Ireland. He remarks at one stage, "That's potato famine anniversary has turned into one interest-bearing media account we can't let go of. I'm so thankful the old chiefs donated seven hundred dollars to the starving Irish back in 1847, I could kiss all their graves." And at another point he advises a colleague to "put a wet towel on your head. The more tribal we appear, the more the Irish love us. The more the Irish love us, the more we're able to move our money in and out of their hands." (Howe 24)

Howe has characters in her own novel describe the story as being like that of a B-movie but this does not prevent the book from being serious about its key messages. It is at pains, like Silko's novel above, to connect stories about the impact of colonialism across generations and across geographical divides. It is determined to reaffirm the indestructible nature of American Indian culture in the face of seemingly insurmountable odds (132), forthright in its depiction 
of casinos as the forum for the corrupt "new Indian wars" of the twenty-first century $(114,120)$, equally forthright in its concern to see American Indian history rewritten to emphasize American Indian virtues and capabilities (43) and at all points never fails to link the spiritual world to the action of the novel. Red's negative "horsefly" character represents a spiritual malaise which can only be controlled by spiritual means. Perhaps the primary message of the novel overall is that Choctaw people are the centre of the action. There may be a communality of experience historically with the Irish that is referred to throughout, but the overarching impression the reader is left with is that Choctaw culture is everlasting and more resilient than its recent colonizers have ever imagined. Curiously, while Howe's novel shows an arch awareness of stereotype and how it can be manipulated, it never goes beyond its re-presentation. The Irish and American Indians are imaginatively linked and their shared history as colonized peoples registered but the reader is never taken beyond the level of shamrocks, inevitable Irish melancholy and the curious notion that, rather like a mal-administered charity, a major problem for an acutely violent insurrectionist grouping like the I.R.A. was that of overspending on bureaucracy. Howe's may be a comic novel but in terms of her representations of the Irish and "Irishness" such broad brushstrokes without even recognition of the North/South divide and simplistic representation of a conflict that took away and scarred so many lives is less than funny.

\section{In conclusion}

One reading of these two different and apparently distant post-colonial reciprocal discourses is to suggest that they resonate with aspects of the postCold War movement for recognition of the United States as an imperial nation, a movement exemplified by texts such as Kaplan and Pease's Cultures of United States Imperialism. Here, we could argue, is writing that speaks from the shared platform of the experience of colonialism, writing that sees America as Niall Ferguson would have us all see it, as an Empire (Ferguson 2003, 2004). Such a stance is one with which many on the left who have been analyzing United States imperialism in depth for decades prior to Ferguson's plea ${ }^{22}$ would agree, but even more is at play here. The question remains, why are the examples of representation of American Indian peoples by the Irish and of Irish people by the American Indians presented here both constrained by the same stereotypes that were originally invented by colonizing nations and why has the critical response to such stereotyping failed to recognize it as such? It may be that a fuller analysis of the phenomenon, analogous to Lennon's sustained analysis of Irish Orientalism, will reach similar conclusions to those Lennon put forward in his study of the Irish gaze when directed towards Asia, West Asia, and North Africa, that such stereotyping is simultaneously both strategic in its deployment and implicit in perpetuating imperialist discourse. 
Perhaps the best way to begin the process of moving beyond mutual stereotyping by Irish and American Indian artists and critics is simply to continue the work of retrieving the long history of shared colonialist experience and understanding so as to allow this to gradually inform each set of discourses. This may not in every instance be an easy journey since, as it did for Roger Casement experiencing the Congo Free State in 1890, it may lead inexorably to an acute awareness not of nationalist identity or of racism exclusively but of the shared suffering that has accompanied the operations of capitalism over time. Casement, who crossed paths with Joseph Conrad serving as a British consul in the Congo, claimed that it was his knowledge of Irish history that allowed him to understand the hideous atrocities he found there. He wrote to a friend:
I knew the Foreign Office would not understand the thing, for I realized that I was looking at this tragedy with the eyes of another race of people once hunted themselves, whose hearts were based on affection as the root principle of contact with their fellow men, and whose estimate of life was not something to be appraised at its market price.

He later continued to reinforce this understanding of a shared history of colonial oppression by describing the peasants of Conemara as "white Indians" and by suggesting that it was only through his experiences in another colonial context that he was able to comprehend his own sense of self: "In these lonely Congo forests where I found Leopold [King of the Belgians, and owner of the Congo Free State], I found also myself, an incorrigible Irishman" (Inglis, Roger Casement 46, 131, 234).

The challenge, as Frantz Fanon explained, is not to take over the place of the colonizer in terms of discourse, but to displace the colonial world and its stereotypes completely. As he puts it in The Wretched of the Earth;

To break up the colonial world does not mean that after the frontiers have been abolished lines of communication will be set up between the two zones. The destruction of the colonial world is no more and no less than the abolition of one zone, its burial in the depths of the earth or its expulsion from the country (41).

Irish and American Indian artists and critics have a choice in terms of what aspects of colonial culture they perpetuate and which aspects they choose wholly to displace. Paradoxically, this involves knowledge of aspects of history and its associated stereotypes in order to choose to liberate oneself from them. To give Fanon the last word, this time in Black Skins, White Masks, the challenge is to make a new representational foundation discrete from those inherited from the 
colonial past. As he puts it: "History's density does not determine any of my acts. I am my own foundation. It is by overcoming what has been historically given, the instrumental, that I start the cycle of my freedom" (205-6). It is to be hoped that the diverse set of discourses that constitute Irish and American Indian contemporary creativity and criticism will set about constructing this new foundation and in so doing move representation of what is Irish and what is American Indian onto new, truly post-colonial ground.

\section{Notes}

1. The debate over whether American Indian experience is imperial, colonial, postcolonial, or neo-colonial is ongoing, see Van Alstyne, The Rising American Empire; Kaplan and Pease, eds., Cultures of United States Imperialism; and McClintock 291-304. There is, of course, no consensus that the "forged concept" of colonialism, as David Lloyd puts it, is adequate to describe the Irish context either (44); See Lloyd and Bartlett 44-59.

2. Seneca Iroquois Arthur Parker (1881-1955) identified the problem of having to "play American Indian" (see Porter, "Introduction," To Be Indian), and Philip Deloria has powerfully contextualized the phenomena in Playing American Indian, 10-70. President of Ireland Mary Robinson's 1995 commemoration of the Choctaw's donation to the famine-struck Irish however had nothing to do with "playing American Indian," and there is no direct link to postcolonial theory in the way that Cullingford suggests. The Choctaw donation was $\$ 710$ in 1847 , a substantial amount given the circumstances, not $\$ 170$ as Cullingford states (Ireland's Others, 173). The commemoration was a positive transcultural event because, as a participant pointed out, "Hunger is the same, no matter where the people are" (Bishinik 31).

3. Youth is central to the American dream and many western heroes are called "kid," as in "Billy the Kid," "the Comanche Kid," and "the Ringo Kid," etc., something Louis Owens suggests, testifying "to America's desire to hold to a self-willed innocence associated with a preadult state" (103).

4. For a path-breaking discussion of how non-American Indian culture obsessively relegates American Indian culture to a static past, see Fabian, Time and the Other.

5. One strong voice is that of Elizabeth Cook-Lynn in, among many publications, AntiAmerican Indianism in Modern America: A Voice From Tatekeya's Earth.

6. See Utley 19, 156 and footnote 27, 290.

7. See Gump, The Dust Rose Like Smoke. This point is contingent and complex, since evidence of Sioux displacement of other peoples has been used to attack legislation for the return of the Black Hills to the Sioux nation. For a forthright discussion and contextualization of the issue, see Cook-Lynn, Anti-American Indianism in Modern America, 52-65. The Pawnee, it is worth noting, were particularly badly served in terms of historical accuracy as a result of Dances With Wolves, transposition from Michael Blake novel to Kevin Costner film. See Blake, Dances With Wolves.

8. See C. L. Sonnichsen 5-34.

9. For an old, but respected history of Geronimo see Debo 13.

10. C. L. Sonnichsen 26. See also Roberts, Once They Moved Like the Wind. The shouting "GERONIMO!" tradition stems from U.S. soldiers copying a movie, probably Geronimo (1939). It is attributed to Private Aubrey Eberhardt who used Geronimo's name to assuage the fears of the U.S. Army's Test Platoon, soldiers at Fort Benning's 29th Infantry Regiment in Georgia, June 1940 as they prepared for the first mass parachute jump. An Phoblacht, "Native Americans-nations in struggle for survival:" Interview with Vernon Bellecourt. 2007.

11. Census of Population and Housing: 1990 Census. U.S. Census Bureau, 1990. Web. 4 Jun.

12. Ward Churchill qtd. in Krupat 30.

13. Poverty in Indian Country Still Higher Than Average. Indianz.com, 31 August 2005. Web. 4 Jun. 2007.

14. For Deane, ("Joyce the Irishman," 37, 41), Joyce has the effect of a missionary, his tool a "nicely polished lookingglass" which he uses to liberate the Irish people. I disagree. It is not through the mirror and the image that Joyce brings liberation but through creating in his readers the ungodly spirit that allows reflexive comprehension of the shifting self. It is perhaps worth noting that Joyce's two young central male characters "play Indian" in "An Encounter" (Dubliners) and it is the desire for adventure the experience prompts that leads them to meet the sinister man in the field at Ringsend.

15. For a discussion of Powwow Highway, see Kilpatrick 113-120.

16. A text not covered in this analysis that deals directly with Irish/Native American connections is Mac Gabhann, Rothar Mór an tSaoil. 
17. The issue of the city's proper name is so violently contested that those who favor peace and who wish to avoid perpetuating blame, often refer to it as Derry/Londonderry or, for short, "Stroke City."

18. I have not dealt in detail here with the singular approach to the Great Famine expressed in Gardens but at a minimum, it is worth noting that David W. Miller, "Irish Presbyterians and the Great Famine," has shown that the impoverished Protestant underclass were as vulnerable to the crisis of 1845-52 as the Catholic labourers in the South and West of Ireland and that Silko's version contradicts much within respected studies such as ÓGráda, Black'47 and Beyond (1999) and McLean, The Event and Its Terrors (2004).

19. For more on "Stroke City," see O'Brien and Nolan, Derry \& Londonderry. Ironically, "St Columba's Greeting to Ireland" speaks of Derry as "my little oak grove of Erin and concludes "As you view it afar from Derry belovèd/ O the peace of it, the peace and delight!" (Graves, A Celtic Psaltery, 17).

20. See for example, Lennon, The Celt and the Oriental.

21. This point was ably made by David Harvey when he asks 'what, if anything, is new about all this?' (Harvey, The New Imperialism, 6, 7). Highly able previous discussions of the United States as an empire include Walter A. McDougall, Promised Land, Crusader State (1997) and A. J. Bacevich, American Empire (2002).

\section{Works Cited}

Armas, Genaro C. MM11. CBS News. 30 Oct. 2002.

Arnold, Matthew. The Study of Celtic Literature. London: Smith, Elder \& Co., 1867.

Attridge, Derek, ed. The Cambridge Companion to James Joyce. Cambridge, U.K.: Cambridge University Press, 1990.

Bacevich, A. J. American Empire: The Realities and Consequences of U.S.

Diplomacy. Cambridge: Harvard University Press, 2002.

Bartlett, Thomas. "'What Ish My Nation?:” Themes in Irish History, 1550-1850,'

Irish Studies: A General Introduction. Ed. Thomas Bartlett, et. al. Dublin:

Gill \& Macmillan, 1988.

Bishinik, The Official Publication of the Choctaw Nation of Oklahoma. "President of Ireland Mary Robinson Addresses the Choctaw People,” June 1995.

Blake, Michael. Dances With Wolves. New York: Ballantine, 1998.

Canny, Nicholas. Kingdom and Colony: Ireland in the Atlantic World, 1560-1800.

Baltimore: Johns Hopkins University Press, 1988.

Canny, Nicholas and Anthony Pagden, eds. Colonial Identity in the Atlantic World, 1500-1800. Princeton: Princeton University Press, 1987.

Census of Population and Housing: 1990 Census. U.S. Census Bureay, 1990.

Web. 4 Jun. 2007. [ http://www.census.gov/prod/www/abs/decennial/1990. htm Accessed 4th June 2007.

Cook-Lynn, Elizabeth. Anti-Indianism in Modern America: A Voice From Tatekeya's Earth. Urbana: University of Illinois Press, 2001.

Cullingford, Elizabeth Butler. Ireland's Others: Ethnicity and Gender in Irish Literature and Popular Culture. Cork: Cork University Press, 2001.

Davis, Mary B., ed. Native America in the Twentieth Century: An Encyclopedia.

New York: Garland Publishing, 1996.

Deane, Seamus. "Joyce the Irishman," Images, Icons and the Irish Nationalist Imagination. Ed. Lawrence W. McBride. Dublin: Four Courts Press, 1999. 
Debo, Angie. Geronimo: The Man, His Time, His Place. London: Pimlico, 1976. Deloria, Philip. Playing Indian. New Haven: Yale University Press, 1998.

Deloria, Vine Jr. God is Red: A Native View of Religion. Colorado: Fulcrum Publishing, 1992.

Duran, Eduardo. Transforming the Soul Wound: A Theoretical and Clinical Approach to Native American Psychology. Berkeley, CA: Folklore Institute, 1990.

Duran, Eduardo and Bonnie Duran. Native American Postcolonial Psychology. Albany: State University of New York Press, 1995.

Fabian, Johannes. Time and the Other: How Anthropology Makes Its Object. New York: Columbia University Press, 1983.

Fanon, Frantz. The Wretched of the Earth. Trans. Constance Farrington. New York: Grove Weidenfeld, 1963.

Fanon, Frantz. Black Skin, White Masks. New York: Grove Press, 1967.

Ferguson, Naill. Empire: The Rise and Demise of the British World Order and Lessons for Global Power. New York: Basic Books, 2003.

Ferguson, Naill. Colossus: The Rise and Fall of the American Empire. London: Penguin Books, 2004.

Gimbutas, Marija. The Goddesses and Gods of Old Europe, 6500-3500 B.C.: Myth, Legends and Cult Images. London: Thames \& Hudson, 1974.

Graves, Alfred Perceval. A Celtic Psaltery Being Mainly Renderings in English Verse From Irish and Welsh Poetry by Alfred Perceval Graves. New York: F.A. Stokes Company, 1917.

Gump, James O. The Dust Rose Like Smoke: The Subjugation of the Zulu and the Sioux. Lincoln: University of Nebraska Press, 1994.

Harvey, David. The New Imperialism. Oxford: Oxford University Press, 2003. Hurtado, Albert L. and Peter Iverson, eds. Major Problems in American Indian History. Lexington: D.C. Heath \& Co, 1994.

Howe, LeAnne. Shellshaker. San Franscisco: Aunt Lute Books, 2001.

Howe, Stephen. Ireland and Empire. Oxford: Oxford University Press, 2000.

Inglis, Brian. Roger Casement. London: Hodder Paperbacks, 1974.

Joyce, James. Dubliners. London: Penguin Books, 1914.

Joyce, James. A Portrait of the Artist as a Young Man. New York: Viking Press, 1956.

Kane, Katie. "Nits Make Lice: Drogheda, Sand Creek, and the Poetics of Colonial Extermination." Cultural Critique 42 (Spring 1999): 81-103. Print.

Kaplan, Amy. The Anarchy of Empire in the Making of U.S. Culture. Cambridge: Harvard University Press, 2005.

Kaplan, Amy and Donald E. Pease, eds. Cultures of United States Imperialism. Durham: Duke University Press, 1993.

Kilpatrick, Jacquelyn. Celluloid Indians: Native Americans and Film. Lincoln: University of Nebraska Press, 1999.

Krupat, Arnold. "Postcoloniality and Native American Literature." The Yale Journal of Criticism 7.1 (1994): 163-180. 
Lennon, Joseph Allen. "The Celt and the Oriental: the Narratives of Irish Orientalism "William Butler Yeats, James Stephens, James Cousins.” Diss. U of Connecticut, 2000.

Lennon, Joseph Allen. Irish Orientalism: A Literary and Intellectual History. Syracuse: Syracuse University Press, 2004.

Lloyd, David. "Introduction." Ireland After History. Cork: Cork University Press, 1999. 1-18.

Mac Gabhann, Micí. Rothar Mór an tSaoil. Trans. by Valentine Iremonger as The Hard Road to Klondyke. London: Routledge \& Kegan Paul, 1973.

Mahaffy, John Pentland. Twelve Lectures on Primitive Civilizations and Their Physical Conditions. London: Longmans, Green, 1869.

Mason, Ellsworth and Richard Ellman, eds. The Critical Writings of James Joyce. New York: Viking, 1964.

Mason, Peter. Deconstructing America: Representations of the Other. London: Routledge, 1990.

Mattar, Sinead Garrigan, Primitivism, Science, and The Irish Revival. Oxford: Oxford University Press, 2004.

McDougall, Walter A. Promised Land, Crusader State: The American Encounter with the World Since 1776. Boston: Houghton Mifflin, 1997.

McLean, Stuart. The Event and Its Terrors: Ireland Famine, Modernity. Stanford: Stanford University Press, 2004.

McClintock, Ann. "The Angel of Progress: Pitfalls of the Term 'Post-Colonialism." Colonial Discourse and Post-Colonial Theory. Eds. Patrick Williams and Laura Chrisman. New York: Columbia University Press, 1994.

McCurry, Jacqueline. “A land 'Not' Borrowed but 'Purloined': Paul Muldoon's Indians.” New Hibernia Review 7.3 (1997): 40-51.

Miller, David W. "Irish Presbyterians and the Great Famine." Luxury \& Austerity: Historical Studies 21. Ed. Jacqueline Hill and Colm Lennon. Dublin: University College Dublin Press, 1999.

Momaday, N. Scott. "The Man Made of Words." Indian Voices: The First Convocation of American Indian Scholars. San Francisco: Indian Historian Press, 1970.

"Native Americans-nations in struggle for survival: Interview with Vernon Bellecourt." An Phoblacht 4 May, 1995.

O'Brien, Gerard and W. Nolan, Derry and Londonderry. Dublin: Geography Publications, 1999.

ÓGráda, Cormac. Black '47 and Beyond: The Great Irish Famine in History, Economy and Money. Princeton: Princeton University Press, 1999.

Owens, Louis. Mixedblood Messages: Literature, Film, Family, Place. Norman: University of Oklahoma Press, 1998.

O’Toole, Fintan. The Lie of the Land: Irish Identities. London: Verso, 1997.

Porter, Joy. To Be Indian: The Life of Arthur Caswell Parker. Norman: University of Oklahoma Press, 2001. 
Poverty in Indian Country Still Higher Than Average. Indianz.com, 31 August 2005, http://www.indianz.com/News/2005/010108.asp.

Quinn, David B. "Sir Thomas Smith and the Beginnings of English Colonial Theory." Proceedings of the American Philosophical Society 89.4 (1945): 543-6.

Rawson, Claude. “'Indians' and Irish: Montaigne, Swift, and the Cannibal Question." Modern Language Quarterly 53.3, (1992): 299-363.

Roberts, David. Once They Moved Like the Wind: Cochise, Geronimo and the Apache Wars. London: Pimlico, 1999.

Silko, Leslie Marmon. Gardens in the Dunes. New York: Simon \& Schuster, 1999.

Sonnichsen, C. L. "From Savage to Saint: A New Image for Geronimo." Geronimo and the End of the Apache Wars. Ed. C. L. Sonnichsen. Lincoln: University of Nebraska Press, 1986.

Spivak, Gayatri. Interview by Sarah Harasym. The Post-Colonial Critic: Interviews, Strategies, Dialogues. Ed. Sarah Harasym. London: Routledge, 1990.

Utley, Robert M. The Lance and the Shield: The Life and Times of Sitting Bull. London: Pimlico, 1993.

Van Alstyne, Richard W. The Rising American Empire. New York, Norton, 1974. 
